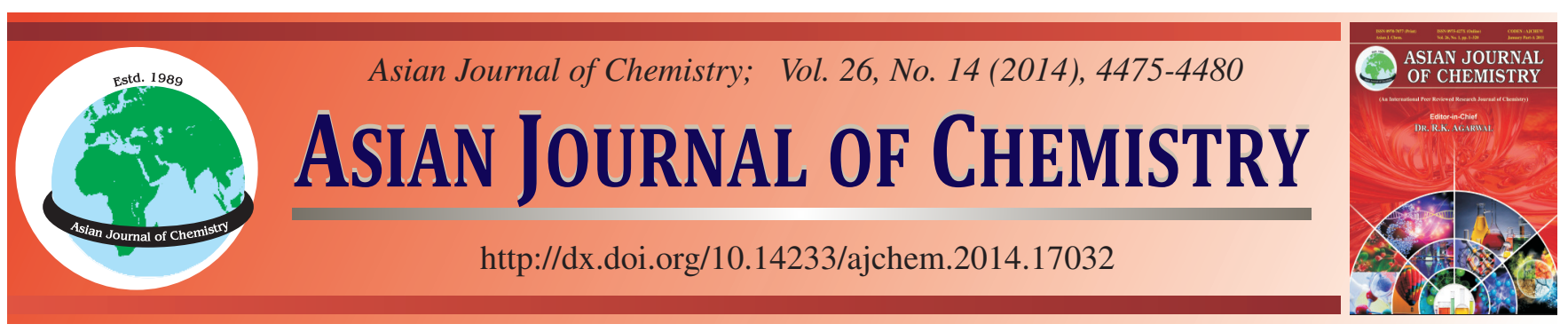

\title{
Modeling of Heavy Metals Adsorption by Inorganic Particles and Activated Sludge in Domestic Wastewater Treatment Plant
}

\author{
Dejun KAnG ${ }^{1, *}$, Danyu XIE ${ }^{1}$ and Pengzhen KE ${ }^{2, *}$
}

${ }^{1}$ School of Municipal Engineering, Department of Civil Engineering, Fuzhou University, No 2, Xueyuan Road, University Town, Fuzhou 350108, Fujian, P.R. China

${ }^{2}$ Hubei Environmental Monitoring Station, Wuhan 430070, P.R. China

*Corresponding authors: Tel: +86 27 87643495; E-mail: djkang@fzu.edu.cn; arc_arc@163.com

\begin{abstract}
In order to verify whether a conventional wastewater treatment process can provide sufficient protective screen of heavy metals, a longterm regular monitoring of different stages of a wastewater treatment plant was conducted. Through a series of adsorption experiments using quartz sand, kaolin of known size distribution as inorganic adsorbents and laboratory-cultured activated sludge as organic adsorbent for adsorbing model of the $\mathrm{Cu}$ and $\mathrm{Zn}$, it was found that the adsorption of heavy metals by the inorganic adsorbents well followed by the Langmuir isotherm with the saturation capacity proportional to the specific surface area of the solid particles, indicating a single-layer adsorption property. However for the activated sludge, its adsorption isotherm showed a property of multilayer adsorption and the adsorption capacity was one order higher than the inorganic particles. Models obtained from the adsorption experiment were practical and can provide an approach to predicting the contents of heavy metals in the wastewater treatment plant's effluent.
\end{abstract}

Keywords: Activated sludge, Adsorption isotherm, Heavy metal, Inorganic particles.

\section{INTRODUCTION}

Industrial and human activities and storm water runoff are the main origin of metals in urban wastewater ${ }^{1}$. The heavy metal contamination was different from other types of pollution, with the ability of concealed, bioaccumulated, long-term existed and unreversed ${ }^{2,3}$. In addition, these ions are non-degradable and persistent, causing both ecological and health problems even at low concentrations ${ }^{4}$. So it is required to minimize heavy metal concentration in water and solid.

There are many methods to remove heavy metals from wastewater including chemical precipitation, chemical oxidation, ion exchange, etc. However, most of these processes need to solve a solid disposal problem and therefore considered to be ineffective and environmentally harmful ${ }^{5}$. On the contrary, activated sludge process in a wastewater treatment plant can not only remove organic matter such as $\mathrm{COD}, \mathrm{BOD}, \mathrm{NH}_{4}-\mathrm{N}$ and total phosphorus in wastewater, but also reduce the content of heavy metals by precipitation, adsorption or biodegradation with lower operating cost and similar even higer efficiency, which is considered to be a side benefit of activated sludge process $^{1,6}$. Besides activated sludge process, other novel biological treatment technology for removing heavy metals had been developed rapidly in recent years ${ }^{7,8}$. At present, the research of heavy metal removal by activated sludge is mainly focused on: (1) the occurrence of heavy metals during a wastewater treatment plant ${ }^{1,9},(2)$ the modeling heavy metal uptake ${ }^{10}$, (3) the mechanism of absoption ${ }^{11}$ and (4) the factors affecting heavy metal adsorption and the impact of heavy metal on the microorganisms, etc. ${ }^{12-14}$.

But few studies by far have systematically investigated heavy metals fading at different stages of wastewater treatment and there is yet sufficient information or knowledge on the characteristics of interaction between heavy metal and inorganic particles versus that between heavy metals and activated sludge particles. The present work was thus aiming at clarifying these actions and related mechanisms by conducting both field investigation and laboratory experiment.

\section{EXPERIMENTAL}

According to the process flow (Fig. 1) of one urban wastewater treatment plant in Xi'an, Shaanxi province in China, four sampling points were picked, which were fine screen, primary settler, oxidation ditch and secondary sedimentation settler. The designed capacity of the wastewater treatment plant treatment was about $100000 \mathrm{~m}^{3} \mathrm{~d}^{-1}$, with Orbal Oxidation Ditch and Reuse System. Samples were weekly collected between May 18, 2008 and July 6, 2009, from the end of four facilities and brought back to the laboratory immediately for quality analysis. 


\begin{tabular}{|c|c|c|c|c|c|c|}
\hline$\underset{\text { Influent }}{\stackrel{\mathrm{S} 1}{\longrightarrow}}$ & $\begin{array}{c}\text { Primary } \\
\text { settler }\end{array}$ & $\mathrm{S} 2$ & $\begin{array}{c}\text { Oxidation } \\
\text { ditch }\end{array}$ & $\mathrm{S} 3$ & $\begin{array}{l}\text { Secondary } \\
\text { settler }\end{array}$ & $\begin{array}{l}\text { S4 } \\
\text { Effluent }\end{array}$ \\
\hline & & & Sludge retu & & Ex & \\
\hline
\end{tabular}

Fig. 1. Schematic flow diagram and sampling point of the wastewater treatment plant

Sample pretreatment: The sample preparation procedure was as follows: The samples were centrifuged at 10,000 rpm for $0.5 \mathrm{~h}$ (SORVALL RC 6 Plus, Thermo) to separate the sludge from the supernatant. The supernatant were filtrated through $0.45 \mu \mathrm{m}$ filter membrane and the filtrates were chosen as aqueous phase. The aqueous phase was stored at $4{ }^{\circ} \mathrm{C}$ before analysis. Then the sediment was air dried at room temperature, which was treated as solid phase. It was then crushed by the agate mortar, following be sieved through 100 mesh nylon sieve. Then the sludge gathered were digested using the ISO method.

Analysis of heavy metal ions: In this study, seven metal ions were targeted e.g., $\mathrm{Cu}, \mathrm{Zn}, \mathrm{Pb}, \mathrm{Cd}, \mathrm{Cr}, \mathrm{Hg}$ and $\mathrm{As}$, among which $\mathrm{Cu}, \mathrm{Zn}, \mathrm{Cd}$ and $\mathrm{Pb}$ were analyzed using atomic absorption spectroscopy (Avanta PM, GBC), Hg and As were determined by hydride generation atomic absorption spectrometry (WHG-103 Peking Hanshi Manufacturing), while Cr was analyzed using ICP-MS (Elan DRC-e, PE). All the vessels were immersed in $20 \%$ analytical grade nitric acid for several hours and then flushed with ultrapure water for three times (Elix, Milli-Q). All experiments were performed in triplicate.

Adsorbents: In this study, quartz and kaolin bought from Sinopharm Chemical Reagent Co., Ltd. were chosen as inorganic adsorbent with different diameter and different specific surface area and stabilized activated sludge were chosen as organic adsorbent. Each inorganic adsorbent was air dried, lightly grained by sieving through 100 mesh nylon sieve and the particle size distribution was measured using a laser particle size analyzer (LS230/SVM+, Beckman Coulter), while the specific surface area was determined by BET method using a Micromeritics Gemini analyzer (Norcrocc). The size distributions and specific surface area of quartz sand and kailinite used in this investigation were shown in Table-1. It is clear that quartz was about 20 times bigger than kaolinite and quartz has less specific surface area. A lab-scale reactors was operated in a computer-controlled sequencing batch mode according to the following sequence: Unaerated feed, aerated reaction, settling, unaerated sludge withdrawal. The activated sludge

\begin{tabular}{lccc}
\hline \multicolumn{3}{c}{ TABLE-1 } \\
CHARACTERISTICS OF INORGANIC ADSORBENTS \\
\hline Adsorbents & TOC $(\%)$ & $\begin{array}{c}\text { Mean particle } \\
\text { size }(\mu \mathrm{m})\end{array}$ & $\begin{array}{c}\text { Specific surface area } \\
\left(\mathrm{m}^{2} \mathrm{~g}^{-1}\right)\end{array}$ \\
\hline $\begin{array}{l}\text { Quartz sand } \\
\text { Kaolin }\end{array}$ & 0.0065 & 3.674 & 6.38 \\
\hline
\end{tabular}

used for adsorption experiment was cultured in it using synthetic wastewater to obtain sludge with identical characteristics during the experiment. The reactor was regulated sampled (usually once per day) at the end of the reaction for determination of the biomass. In addition, scanning electron microscope (S-3400N, Hitachi) was conducted for morphological observation of the sludge particles, the SEM pictures were shown in Fig. 2.

Adsorption experiments: Batch sorption tests were carried out with $100 \mathrm{~mL}$ of monometallic solutions to a $150 \mathrm{~mL}$ beaker flask. To start the experiment, $100 \mathrm{mg}$ of the individual sorbents (Kaolinite or quartz sand) were introduced to a $100 \mathrm{~mL}$ solution containing heavy metals $\left(10-100 \mathrm{mg} \mathrm{L}^{-1}\right)$. The flask was then transferred to a SHA-B model constant temperature shaker with a thermostat (Changzhou Guohua instrument Co., Ltd, China) and shaken under 160 oscillations per minute for $24 \mathrm{~h}$ at $298 \mathrm{~K}$ to ensure the sorption process can reach equilibrium. $\mathrm{HNO}_{3}(1 \mathrm{M})$ was used to adjust the $\mathrm{pH}$ of solution throughout the experiment when necessary. For the analysis of unabsorbed metal concentration, the acidification of the solution was not necessary since the $\mathrm{pH}$ was always lower than the precipitation values for all metals. The amount of each heavy metal loaded on the sorbent is calculated by conducting a mass balance before and after the test. After shaken, the suspensions were centrifuged at 10,000 rpm for 15 min (SORVALL RC 6 Plus, Thermo). The determination of initial and equilibrium concentrations of $\mathrm{Cu}$ and $\mathrm{Zn}$ was the same as that mentioned above. The amounts of metals adsorption were calculated from the difference between their concentrations in solutions before (initial concentration) and after (equilibrium concentration) adsorption experiments. $\mathrm{pH}$ was also determined in the initial and centrifuged equilibrium solutions. All experiments were performed in triplicate and the average of the results is presented.

\section{RESULTS AND DISCUSSION}

Generally in a wastewater treatment plant, primary settler is designed to remove suspended solid with diameter less than $0.1 \mathrm{~mm}$, while oxidation ditch is designed to remove organic
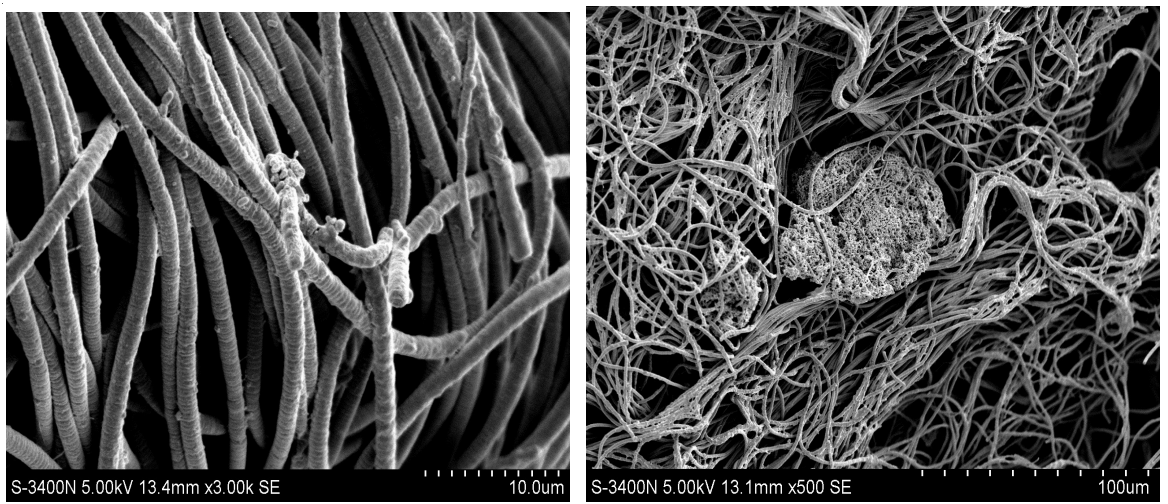

Fig. 2. SEM image of the activated sludge

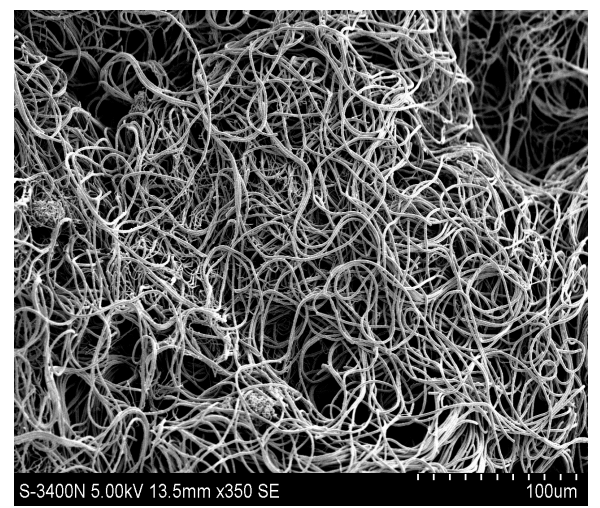

S-3400N $5.00 \mathrm{kV} 13.5 \mathrm{~mm} \times 350$ SE 
matter like $\mathrm{COD}$ and $\mathrm{BOD}, \mathrm{NH}_{4}-\mathrm{N}$ and total phosphorus and the aeration in the oxdization ditch causes a drop in $\mathrm{pH}$. Finally the residual contaminants, especially the heavy metals, are further removed in secondary sedimentation settler since the $\mathrm{pH}$ in secondary settler was a little higher than that in oxidation ditch (Fig. 3).

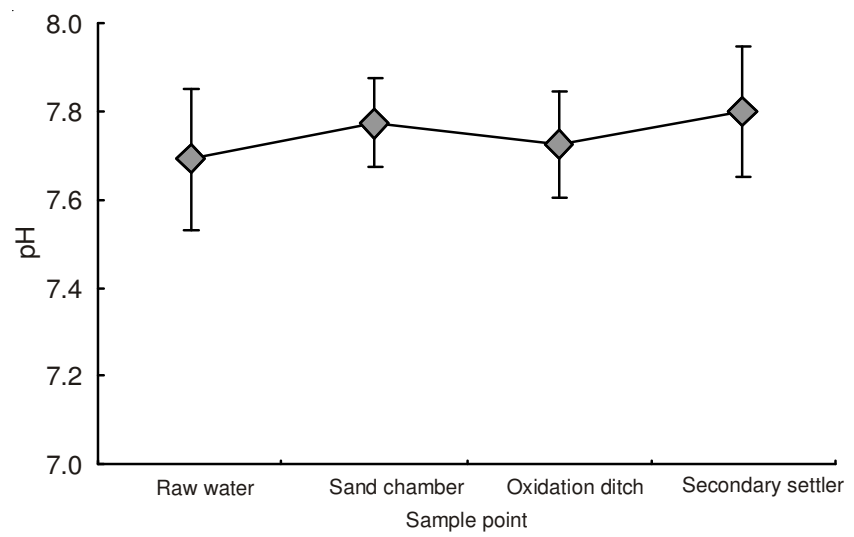

Fig. 3. Vibration of $\mathrm{pH}$ in different stages in wastewater treatment plant

With about one year's consistent monitoring between May 18, 2008 and July 6, 2009 from the wastewater treatment plant in Xi'an, the distribution of these seven dissolved metals in the different stages was shown in Fig. 4. All data was calculated by average and $95 \%$ confidence interval was picked. As shown in Fig. 4, the contents of these seven metals in untreated water were in order of $\mathrm{Zn}>\mathrm{Cr}>\mathrm{Cu}>\mathrm{As}>\mathrm{Cd}>\mathrm{Hg}>\mathrm{Pb}$ and most metals entered the wastewater treatment plant at trace levels $\left(\mu \mathrm{g} \mathrm{L}^{-1}\right)$, among which zinc generally at relatively high concentrations, with $59.8 \mu \mathrm{g} \mathrm{L}^{-1}$ approximately, indicating that urban wastewater in that area was not polluted by heavy metals seriously. Fig. 4 also shows that all the heavy metals were progressively reduced along the treatment process, indicating that four wastewater treatment facilities in wastewater treatment plant own a certain capacity for removing heavy metals, with leaving about several microgram per liter in the effluent. The effluent of wastewater treatment plant was safely for landscope reuses and municipal greening.

Distribution of $\mathrm{Cu}, \mathrm{Zn}, \mathrm{Cd}, \mathrm{Pb}, \mathrm{Cr}, \mathrm{Hg}$ and $\mathrm{As}$ in solid phase: The distribution of these heavy metals in solid phase was also investigated in this study, as summarized in Table-2. All data was calculated by average and $95 \%$ confidence interval was picked. It could be found that $\mathrm{Zn}$ appeared to be the most abundant metal with $1677.9 \mathrm{mg} \mathrm{Zn/kg}$ sludge, which may have something to do with the widely use of galvanized pipe. Mercury exhibited the lowest abundance and their contents were $\mathrm{Zn}, \mathrm{Cr}, \mathrm{Pb}, \mathrm{Cu}, \mathrm{As}, \mathrm{Cd}$ and $\mathrm{Hg}$ in decreasing order, which was slightly different from those in aqueous phase. As mentioned above, $\mathrm{Pb}$ entered the wastewater treatment plant with lowest content in aqueous phase, but it became the third for content in solid phase. It may be resulted from that most of $\mathrm{Pb}$ had already transferred into suspended solids before entering the wastewater treatment plant, $\mathrm{Pb}$ in solid phase almost makes up the total concentration of $\mathrm{Pb}$ during the wastewater treatment plant process. The distribution of heavy metals in solid phase could also evaluate the degree of heavy metal contamination in that area as that in aqueous phase. Besides $\mathrm{Zn}, \mathrm{Cr}$
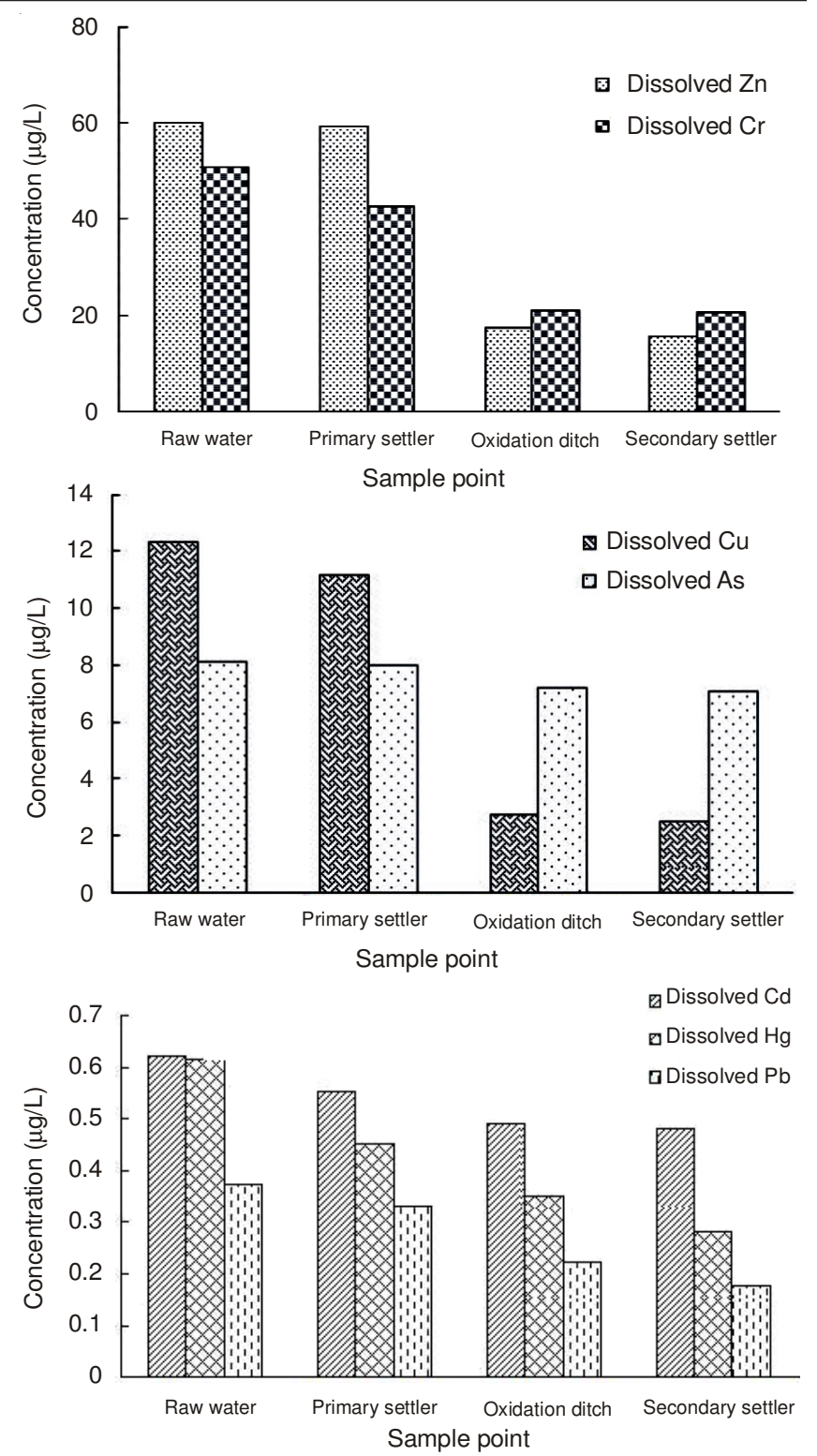

Fig. 4. Average distribution of the dissolved $\mathrm{Cu}, \mathrm{Zn}, \mathrm{Pb}, \mathrm{Cd}, \mathrm{Hg}$ and $\mathrm{As}$ in the different stages

\begin{tabular}{cc} 
TABLE-2 \\
RANGE AND MEAN VALUES OF \\
METALS IN DISCHARGED SLUDGE $\left(\mathrm{mg} \mathrm{kg}^{-1}\right)$ \\
\hline Metal & Mean \pm SD \\
\hline $\mathrm{Cd}$ & $23.2 \pm 3.4$ \\
$\mathrm{Cu}$ & $290.6 \pm 36.8$ \\
$\mathrm{Zn}$ & $1677.9 \pm 194.4$ \\
$\mathrm{~Pb}$ & $381.8 \pm 52.7$ \\
$\mathrm{Hg}$ & $5.22 \pm 1.02$ \\
$\mathrm{Cr}$ & $684.8 \pm 43.2$ \\
$\mathrm{As}$ & $24.59 \pm 4.16$ \\
\hline
\end{tabular}

SD: Standard deviation (with picking $95 \%$ confidence interval)

appeared at a relatively high content, which is necessary to pay more attention.

Metal balance in water treatment process: As above, heavy metals in aqueous phase were transferred into solids during the process of wastewater treatment plant, so there must be a material balance. The decrease of heavy metal concentration in aqueous phase must be equal to the increment of 
that in solid phase. In order to verify the assumption, the material balance of $\mathrm{Cu}$ and $\mathrm{Zn}$ was conducted in this study according to Fig. 5. The material balance equation for each unit can be written as:

$$
\mathrm{QC}_{0}-\mathrm{QC}_{\mathrm{e}}=\Delta \mathrm{C}_{\mathrm{s}} \mathrm{M}
$$

where $\mathrm{Q}$ is the flow $\left(\mathrm{m}^{3} \mathrm{~d}^{-1}\right)$ (to simplify the calculation, we assume that the inflow of a unit was equal to its outflow); $\mathrm{C}_{0}$ and $\mathrm{C}_{\mathrm{e}}$ are the heavy metal concentrations of influent and effluent $\left(\mathrm{g} \mathrm{m}^{-3}\right) ; \Delta \mathrm{C}_{\mathrm{s}}$ is the increment of the heavy metal concentration in the solid phase, which can be calculated from the difference between the contents in solid phase before and after the processing unit and $\mathrm{M}$ is the mass of spoil disposal, for example $\mathrm{M}_{1}\left(\mathrm{SS}_{0}-\mathrm{SS}_{\mathrm{t}}\right) \mathrm{Q}$.

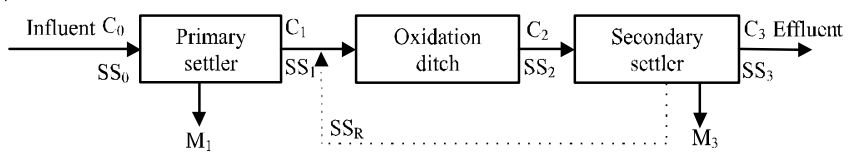

Fig. 5. Material balance along the wastewater treatment plant

The $\mathrm{C}_{\mathrm{s}}$, the decrease of $\mathrm{Cu}$ and $\mathrm{Zn}$ in aqueous phase and the increment in solid phase of primary settler and activated sludge process were calculated (Table-3) and the parameters obtained from long-term investigation. The result is shown in Table-4. It can be found from Table-4 that the material balance was indeed existent during the process of wastewater treatment plant, since the decrease of $\mathrm{Cu}$ and $\mathrm{Zn}$ in aqueous phase is consistent with the increment of that in solid phase both for primary settler and activated sludge process.

\begin{tabular}{lcc|cc}
\multicolumn{4}{c}{ TABLE-3 } \\
\multicolumn{3}{c}{$\begin{array}{c}\text { CONTENTS OF Cu AND Zn IN } \\
\text { AQUEOUS PHASE AND SOLID PHASE }\end{array}$} \\
\hline \multirow{3}{*}{ Sample point } & \multicolumn{2}{c}{$\begin{array}{c}\text { Contents in aqueous } \\
\text { phase }\left(\mu \mathrm{g} \mathrm{L}^{-1}\right)\end{array}$} & \multicolumn{2}{c}{$\begin{array}{c}\text { Contents in solid } \\
\text { phase }\left(\mathrm{mg} \mathrm{kg}^{-1}\right)\end{array}$} \\
\cline { 2 - 5 } & $\mathrm{Cu}$ & $\mathrm{Zn}$ & $\mathrm{Cu}$ & $\mathrm{Zn}$ \\
\hline Influent & 12.31 & 59.8 & 243.0 & 1504.6 \\
Primary settler & 11.16 & 59.2 & 256.8 & 1510.7 \\
Oxidation Ditch & 2.75 & 17.2 & 282.6 & 1644.3 \\
Secondary settler & 2.50 & 15.6 & 290.6 & 1677.9 \\
\hline
\end{tabular}

\begin{tabular}{|c|c|c|c|c|}
\hline \multicolumn{5}{|c|}{$\begin{array}{c}\text { TABLE-4 } \\
\text { MATERIAL BALANCE IN THE PRIMARY } \\
\text { SETTLER AND ACTIVATED SLUDGE PROCESS }\end{array}$} \\
\hline \multirow{2}{*}{ Items } & \multicolumn{2}{|c|}{ Primary settler } & \multirow{2}{*}{\multicolumn{2}{|c|}{$\frac{\text { Activated sludge process }}{\mathrm{Zn}}$}} \\
\hline & $\mathrm{Cu}$ & $\mathrm{Cu}$ & & \\
\hline$\Delta \mathrm{C}_{\mathrm{s}}\left(\mathrm{mg} \mathrm{kg}^{-1}\right)$ & 13.8 & 6.1 & 33.8 & 167.2 \\
\hline $\begin{array}{l}\text { Decrease in aqueous } \\
\text { phase }\left(\mathrm{kg} \mathrm{d}^{-1}\right)\end{array}$ & 0.097 & 0.051 & 0.731 & 3.678 \\
\hline $\begin{array}{l}\text { Increment in solid } \\
\text { phase }\left(\mathrm{kg} \mathrm{d}^{-1}\right)\end{array}$ & 0.093 & 0.041 & 0.736 & 3.639 \\
\hline
\end{tabular}

\section{Adsorption of heavy metals by inorganic particles and activated sludge}

Theoretical aspects ${ }^{\mathbf{1 5}}$ : The Langmuir isotherm has been used extensively by many researchers for the sorption of heavy metal ions in clay, metal oxides, soils, etc. The Langmuir isotherm is a valid monolayer absorption on a surface containing a finite number of binding sites. It assumes uniform energies of sorption on the surface and no transmigration of sorbate in the surface. The Langmuir equation may be written as:

$$
\begin{gathered}
\mathrm{q}_{\mathrm{c}}=\frac{\mathrm{q}_{\max } \mathrm{bC}_{\mathrm{e}}}{1+\mathrm{bC}_{\mathrm{e}}} \text { (non-linear form) } \\
\frac{1}{\mathrm{q}_{\mathrm{c}}}=\frac{1}{\mathrm{q}_{\max }}+\frac{1}{\mathrm{q}_{\max } \mathrm{b}} \times \frac{1}{\mathrm{C}_{\mathrm{e}}} \text { (linear form) }
\end{gathered}
$$

where $\mathrm{q}_{\mathrm{e}}$ is the amount of solute adsorbed per unit weight of adsorbent $\left(\mu \mathrm{g} \mathrm{g}^{-1}\right) ; \mathrm{C}_{\mathrm{e}}$ is the equilibrium concentration of solute in the bulk solution $\left(\mu \mathrm{g} \mathrm{L}^{-1}\right) ; \mathrm{q}_{\max }$ is the monolayer adsorption capacity $\left(\mu \mathrm{g} \mathrm{g}^{-1}\right)$; b is the constant related to the energy of adsorption and it is the value reciprocal of the concentration at which half the saturation of the adsorbed is attained.

Adsorption isotherms: As known to all, the possibility of $\mathrm{Cu}^{2+}, \mathrm{Zn}^{2+}$ ions being precipated as hydroxides at $\mathrm{pH}$ of experiment during adsorption was examined. The $\mathrm{K}_{\mathrm{sp}}$ values of $\mathrm{Cu}(\mathrm{OH})_{2}$ and $\mathrm{Zn}(\mathrm{OH})_{2}$ are $4.8 \times 10^{-20}$ and $1.8 \times 10^{-14}$, respectively ${ }^{16}$. The $\mathrm{pHs}$ for precipitation of $\mathrm{Cu}^{2+}, \mathrm{Zn}^{2+}$ from a $100 \mu \mathrm{g}$ $\mathrm{L}^{-1}$ solution are $7.24,10.04$. The significance of the adsorption isotherms is that they present the concentration dependent equilibrium distribution towards adsorbate between the solution and the adsorbent at certain conditions. Fig. 6 shows the adsorption isotherms of $\mathrm{Cu}$ and $\mathrm{Zn}$ using the three types of the adsorbent mentioned above at $298 \mathrm{~K}$. The constants for the two ions in addition to $\mathrm{R}^{2}$ values for each line are also shown in Fig. 6. It can be seen from these figures that activated sludge gives the highest value of $\mathrm{q}_{\max }$, indicating that adsorbents with different particle size and specific surface area have different capacity to adsorb metal ions, the larger specific surface area is, the higher value of $\mathrm{q}_{\max }$ is. In conclusion, the affinity of the adsorbents towards $\mathrm{Cu}$ and $\mathrm{Zn}$ is as follows: activated sludge $>$ kaolinite $>$ quartz.

Modeling of heavy metal removal in wastewater treatment plant: In order to explain how $\mathrm{Cu}, \mathrm{Zn}$ were removed in the wastewater treatment plant using the information obtained from adsorption experiment, a set of mathematic models were developed following the principle of material balance. As above, the material balance could be conducted under an assumption that in the primary settler, heavy metals removal was only performed by adsorption on to inorganic particles, while in the oxidation ditch, the effect of volatilization and biodegradation were ignored. For a unit in the treatment process, the material balance can be simply written as

$$
\mathrm{Q}_{0} \mathrm{C}_{0}-\mathrm{Q}_{\mathrm{e}} \mathrm{C}_{\mathrm{e}}=\mathrm{m}
$$

where $\mathrm{Q}_{0}$ and $\mathrm{Q}_{\mathrm{e}}$ are the inflow and outflow of this unit $\left(\mathrm{m}^{3}\right.$ $\left.\mathrm{d}^{-1}\right) ; \mathrm{C}_{0}$ and $\mathrm{C}_{\mathrm{e}}$ are the heavy metal concentrations of influent and effluent $\left(\mathrm{g} \mathrm{m}^{-3}\right)$; and $\mathrm{m}$ is the mass of heavy metals removal in this unit $\left(\mathrm{g} \mathrm{d}^{-1}\right)$. To simplify the calculation, we assume that $\mathrm{Q}_{\mathrm{e}} \approx \mathrm{Q}_{0}$ when the flow for desludging is neglected.

As the heavy metals are removed by their adsorption onto particles, the mass of heavy metals removal can be evaluated as

$$
\mathrm{m}=\mathrm{M}_{\mathrm{p}} \mathrm{K}_{\mathrm{p}} \mathrm{C}_{\mathrm{e}}
$$

where $\mathrm{M}_{\mathrm{p}}$ is the mass of solid particles in processing unit $\left(\mathrm{g} \mathrm{d}^{-1}\right)$; $\mathrm{K}_{\mathrm{p}}$ is the partition coefficient of heavy metals in it $\left(\mathrm{m}^{3} \mathrm{~g}^{-1}\right)$. Substituting eqn. 5 into eqn. 4 will yield 

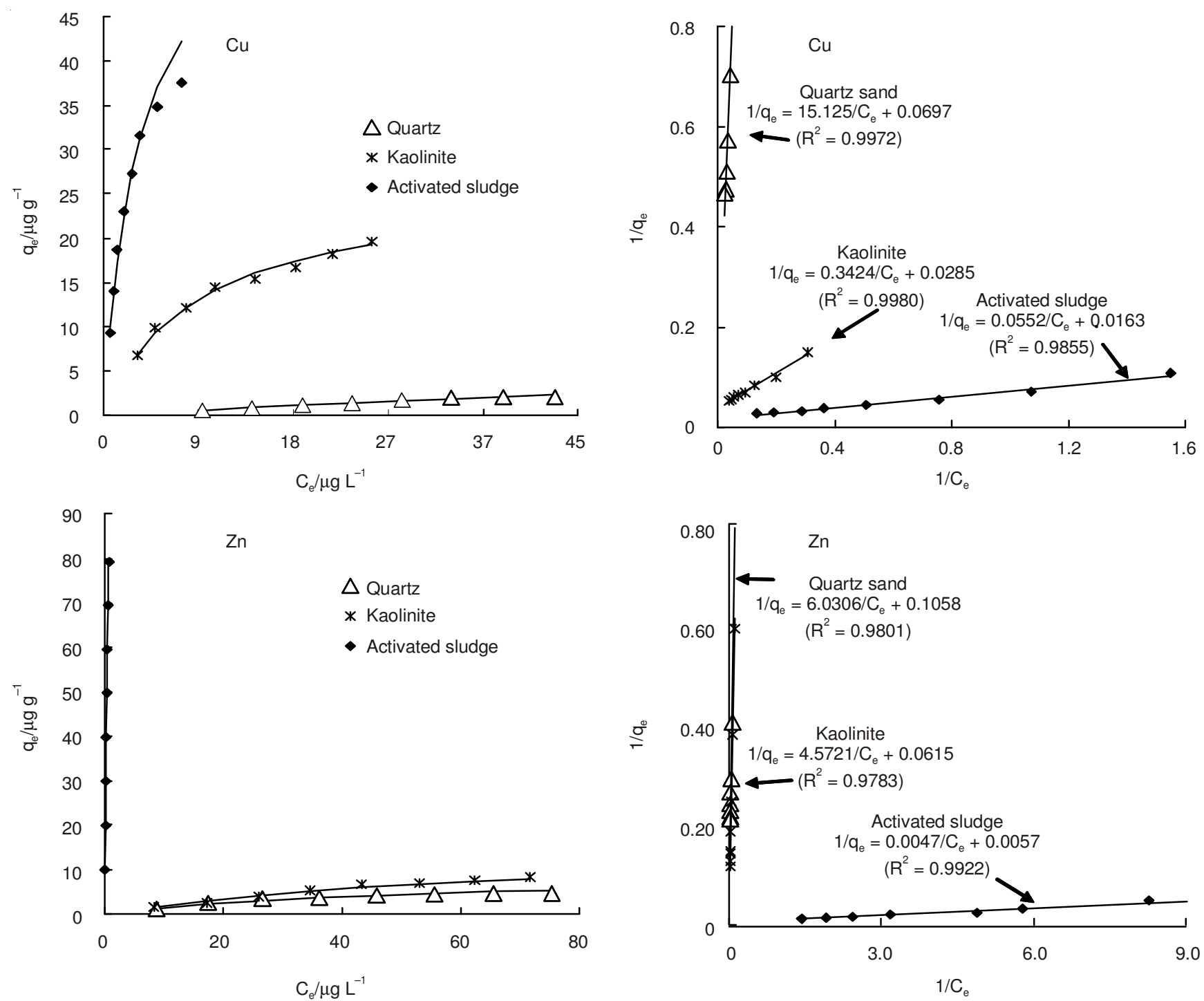

Fig. 6. Adsorption isotherms for $\mathrm{Cu}$ and $\mathrm{Zn}$ using the three types of adsorbent. Temperature $=25^{\circ} \mathrm{C}, \mathrm{pH}=6$, mixing speed $=160$ rpm, adsorbent concentration $=1000 \mathrm{mg} \mathrm{L}^{-1}$ MLSS, solution volume $=100 \mathrm{~mL}$, contact time $=24 \mathrm{~h}$

$$
\mathrm{Q}_{0} \mathrm{C}_{0}-\mathrm{Q}_{\mathrm{e}} \mathrm{C}_{\mathrm{e}}=\mathrm{M}_{\mathrm{p}} \mathrm{K}_{\mathrm{p}} \mathrm{C}_{\mathrm{e}}
$$

and the removal of heavy metals in this unit can be calculated as

$$
\mathrm{R}=\frac{\mathrm{C}_{0}-\mathrm{C}_{\mathrm{c}}}{\mathrm{C}_{0}}=\frac{\mathrm{M}_{\mathrm{p}} \mathrm{K}_{\mathrm{p}}}{\mathrm{M}_{\mathrm{p}} \mathrm{K}_{\mathrm{p}}+\mathrm{Q}_{0}}
$$

And the adsorption follows the Langmuir adsorption model,

(1) if $\mathrm{bC}_{\mathrm{e}}<<1$, it can be assumed that $1+\mathrm{bC}_{\mathrm{e}} \approx 1$

$$
\begin{gathered}
\mathrm{K}_{\mathrm{p}}=\frac{\mathrm{q}_{\mathrm{e}}}{\mathrm{C}_{\mathrm{e}}}=\frac{\mathrm{q}_{\max } \mathrm{b}}{1+\mathrm{bC}} \approx \mathrm{b} \cdot \mathrm{q}_{\max } \\
\mathrm{R}_{\text {cal }}=\frac{\mathrm{C}_{0}-\mathrm{C}_{\mathrm{e}}}{\mathrm{C}_{0}}=\frac{\mathrm{M}_{\mathrm{p}} \mathrm{K}_{\mathrm{p}}}{\mathrm{M}_{\mathrm{p}} \mathrm{K}_{\mathrm{p}}+\mathrm{Q}_{0}}=\frac{\mathrm{M}_{\mathrm{p}} \mathrm{bq} \mathrm{q}_{\max }}{\mathrm{M}_{\mathrm{p}} \mathrm{bq}_{\max }+\mathrm{Q}_{0}}
\end{gathered}
$$

(2) if $b_{e}$ is not much less than 1 and can't be neglected, it can use the following equation,

$$
\mathrm{R}_{\mathrm{cal}}=\frac{\mathrm{M}_{\mathrm{p}} \mathrm{K}_{\mathrm{p}}}{\mathrm{M}_{\mathrm{p}} \mathrm{K}_{\mathrm{p}}+\mathrm{Q}_{0}}=\frac{\mathrm{M}_{\mathrm{p}} \frac{\mathrm{q}_{\max } \mathrm{b}}{1+\mathrm{bC}}}{\mathrm{M}_{\mathrm{p}} \frac{\mathrm{q}_{\max } \mathrm{b}}{1+\mathrm{bC}_{\mathrm{e}}+\mathrm{Q}_{0}}}=\frac{\mathrm{M}_{\mathrm{p}} \mathrm{q}_{\max } \mathrm{b}}{\mathrm{M}_{\mathrm{p}} \mathrm{q}_{\max } \mathrm{b}+\mathrm{Q}_{0}\left(1+\mathrm{bC}_{\mathrm{e}}\right)}
$$

and $\mathrm{C}_{\mathrm{e}}=\mathrm{C}_{0}\left(1-\mathrm{R}_{\text {cal }}\right)$

$$
\text { so, } R_{\text {cal }}=\frac{M_{p} q_{\max } b}{M_{p} q_{\max } b+Q_{0}\left(1+b C_{e}\right)}=\frac{M_{p} q_{\max } b}{M_{p} q_{\max } b+Q_{0}\left[1+b C_{0}\left(1-R_{c a l}\right)\right]}
$$

and the value of $R_{\text {cal }}$ is between zero and 1 , so we should only choose:

$$
\mathrm{R}_{\text {cal }}=\frac{\frac{\mathrm{M}_{\mathrm{p}} \mathrm{q}_{\max } \mathrm{b}+\mathrm{Q}_{0}+\mathrm{bC}_{0} \mathrm{Q}_{0}}{\mathrm{bC}_{0} \mathrm{Q}_{0}}-\sqrt{\left(\frac{\mathrm{M}_{\mathrm{p}} \mathrm{q}_{\max } \mathrm{b}+\mathrm{Q}_{0}+\mathrm{bC}_{0} \mathrm{Q}_{0}}{\mathrm{bC}_{0} \mathrm{Q}_{0}}\right)^{2}-\frac{4 \mathrm{M}_{\mathrm{p}} \mathrm{q}_{\max } \mathrm{b}}{\mathrm{bC}_{0} \mathrm{Q}_{0}}}}{2}
$$

The predicted removal efficiencies of $\mathrm{Cu}$ and $\mathrm{Zn}$ in the primary settler(by quartz and kailinite) and activated sludge process (by quartz, kaolinite and activated sludge) were calculated, respectively with eqn. (9) or eqn. (13). The actual removal efficiencies were also calculated with the data in Table-5. The removal of $\mathrm{Zn}$ and $\mathrm{Cu}$ in the primary settler was supposed to be performed by their adsorption onto inorganic particles, since the predicted removal efficiencies were close to the actual ones achieved by kaolinite. The calculated $K_{p}-R$ relation can reasonably reflect the practical condition in the 
TABLE-5

REMOVAL EFFICIENCIES FOR COPPER AND ZINC

\begin{tabular}{cccc|ccc}
\hline \multirow{2}{*}{$\begin{array}{c}\text { Removal } \\
\text { efficiency }\end{array}$} & \multicolumn{3}{c|}{ Primary settler } & \multicolumn{3}{c}{ Activated sludge process } \\
\cline { 2 - 7 } & $\mathrm{R}_{\text {real }}$ & $\mathrm{R}_{\text {cal-Quartz }}$ & $\mathrm{R}_{\text {cal-Kaolin }}$ & $\mathrm{R}_{\text {real }}$ & $\mathrm{R}_{\text {cal-Quartz }}$ & $\mathrm{R}_{\text {cal-Kaolin }}$ \\
\hline Copper & 0.093 & 0.005 & 0.094 & 0.776 & 0.016 & 0.248 \\
Zinc & 0.010 & 0.006 & 0.010 & 0.736 & 0.021 & 0.031 \\
\hline
\end{tabular}

wastewater treatment plant and the different level of removal for these metals is due to the difference in their equilibrium partitioning coefficient $\mathrm{K}_{\mathrm{p}}$. When it came to activated sludge process, the predicted removal efficiencies obtained by activated sludge were closest to but still lower than the actual ones, indicating that the removal of $\mathrm{Zn}$ and $\mathrm{Cu}$ during activated sludge process was mainly depended on the adsorption onto activated sludge and a fraction of heavy metals might be removed by biodegradation. Taken together, the models developed in this study fit well to the actual removal efficiency of heavy metals in a wastewater treatment plant, which provides a realistic method of predicting the contents of heavy metals in a wastewater treatment plant's effluent when that in influent is known.

\section{Conclusion}

The characteristics of heavy metal removal by conventional wastewater treatment process could be explained under the assumption adsorption onto particle surface may be the main mechanism. The activated sludge has the largest adsorption ability to heavy metals indicating that activated sludge can be easily used as a low cost bioadsorbent for heavy metals. The inorganic particles and activated sludge displayed Langmuir adsorption characteristics. The mathematic models were developed using the information obtained from adsorption experiment, which proved to be very realistic and could be used to predict the contents of heavy metals in a wastewater treatment plant's effluent.

\section{ACKNOWLEDGEMENTS}

This work was supported by the Talent Fund in Fuzhou University (XRC-1268) and the Science and Technology Development Fund in Fuzhou University (2013-XY-23).

\section{REFERENCES}

1. G.E. Üstün, J. Hazard. Mater., 172, 833 (2009).

2. R.B. Owen and N.S. Sandhu, Mar. Pollut. Bull., 40, 174 (2000).

3. R. Zufiaurre, A. Olivar, P. Chamorro, A. Callizo and R. Zufiaurre, Analyst (Lond.), 123, 255 (1998).

4. I. Alkorta, J. Hernández-Allica, J.M. Becerril, I. Amezaga, I. Albizu and C. Garbisu, Rev. Environ. Sci. Biotechnol., 3, 71 (2004).

5. Z. Al-Qodah, Desalination, 196, 164 (2006).

6. M. García-Delgado, M.S. Rodríguez-Cruz, L.F. Lorenzo, M. Arienzo and M.J. Sánchez-Martín, Sci. Total Environ., 382, 82 (2007).

7. M. Inyang, B. Gao, Y. Yao, Y. Xue, A.R. Zimmerman, P. Pullammanappallil and X. Cao, Bioresour. Technol., 110, 50 (2012).

8. H.T.Q. Kieu, E. Müller and H. Horn, Water Res., 45, 3863 (2011).

9. K.B. Chipasa, Waste Manage., 23, 135 (2003).

10. J. Wang, Water Res., 37, 4835 (2002).

11. G.P. Sheng, J. Xu, H.W. Luo, W.-W. Li, W.-H. Li, H.-Q. Yu, Z. Xie, S.Q. Wei and F.-C. Hu, Water Res., 47, 607 (2013).

12. G. Liu, D. Wang, J. Wang and C. Mendoza, Sci. Total Environ., 409, 2852 (2011).

13. E. Vaiopoulou and P. Gikas, Water Res., 46, 549 (2012).

14. V. Ochoa-Herrera, G. León, Q. Banihani, J.A. Field and R. Sierra-Alvarez, Sci. Total Environ., 412-413, 380 (2011).

15. I. Langmuir, J. Am. Chem. Soc., 40, 1361 (1918).

16. J.A. Dean, Lange's Handbook of Chemistry, McGraw-Hill, edn 15 (1999). 